\title{
The 2006 Mexican Elections: Manifestation of a Divided Society?
}

W hen the Institutional Revolutionary Party (PRI) lost the presidency in 2000, the central cleavage that defined Mexican politics in the last 15 years of the twentieth centurypro-regime vs. anti-regime-could no longer guide voters on Election Day. With no PRI to vote out of office (or to defend), Mexicans were impelled to turn their political attention to non-regime issues, such as economic policy, social policy, relations with the United States, and crime control. As Kathleen Bruhn and Kenneth Greene make clear in their contribution to this symposium, Mexican political elites are seriously divided on these issues, while the views of their bases are not far apart.

The issues that animate Mexican political debate may nevertheless arise from important social divisions at the mass level. Were there profound differences in the support bases in social groups among the three main parties and three major presidential candidates in 2006 ? Did social groups with opposing interests on matters of public policy line up behind the parties and candidates who most clearly represented their interests? A prevalent line of analysis posits a "blue-yellow divide" that geographically divides Mexico, much akin to

by Joseph L. Klesner, Kenyon College the "red state-blue state divide" trumpeted by the media in recent U.S. elections. In this view, the nation separates into northern, blue Mexico, where the National Action Party's (PAN) Felipe Calderón won most states and southern, yellow Mexico where Andrés Manuel López Obrador of the Party of the Democratic Revolution (PRD, the core of the Coalition for the Welfare of All) carried most states. ${ }^{1}$ Figure 1 illustrates this blue and yellow cleavage, in grey (states where Calderón won) and white (López Obrador victories).

But just as the U.S. red-blue division both illuminates a central truth about contemporary American politics and masks important complexities below the surface (Gimpel and Schuknecht 2003; Ansolabehere, Rodden, and Snyder 2006; Gimpel and Karnes 2006), Mexican states do not easily fall into the blue and yellow categories. Nor are Mexican sociological categories so simply separated into proPAN and pro-PRD groups. The added complexity of Mexico's three-party system, which includes the continued presence of the PRI, complicates any analysis of cleavage patterns in Mexican politics: the fact that wealthy voters disproportionately favor Calderón does not mean that the poor disproportionately vote for López Obrador. In this article, I provide a brief exploration of the major social and political bases of the top three contenders in this election. In addition, I offer insight on how the campaign dynamics worked in favor of the eventual winner, the PAN's Felipe Calderón, by examining the political characteristics of the three presidential candidates' constituents, with a view to understanding which segments of voters moved to Calderón's camp during the course of the race. In so doing, I underscore the still-fluid character of partisan alignment in Mexico's new democracy.

\section{Evidence}

To explore the social bases of the three major parties' candidacies, I draw on two main sources. First, I use initial returns from the Federal Electoral Institute (IFE) at the state $(\mathrm{N}=32)$, electoral district $(\mathrm{n}=300)$, and precinct levels to examine regional voting patterns. ${ }^{2}$ For individual-level data, I use the Mexico 2006 Panel Study. ${ }^{3}$ Comparisons to two major exit polls conducted by the newspaper Reforma (Reforma Investigación 2006) and by the polling firm Consulta Mitofsky (2006) for the Mexican broadcasting network Televisa suggest that the panel study results are very similar to those in the background population-a conclusion supported by a comparison of the final panel wave with a small cross-section of respondents conducted contemporaneously with the third panel wave. I use the panel study here because it asks a wider range of questions than the exit polls and allows us to explore changes in voting intention over the course of the campaign.

\section{Social Bases of the Mexican Parties}

The López Obrador campaign and the PRD made economic policy a central campaign issue. López Obrador openly criticized the "neoliberal model" for its failure to address distributional justice and suggested that Mexico reconsider one element of the North American Free Trade Agreement (NAFTA). Most observers labeled López Obrador a populist, suggesting that his approach to social policy would emphasize government spending with little concern for the likely impact on broader macroeconomic indicators (for examples, see McKinley 2006). Calderón, meanwhile, promised to hew to the main lines of President Vicente Fox's economic policy, which was in turn similar to that pursued by the preceding PRI governments of Ernesto Zedillo (1994-2000) 


\section{Figure 1}

\section{Blue and Yellow Mexico}

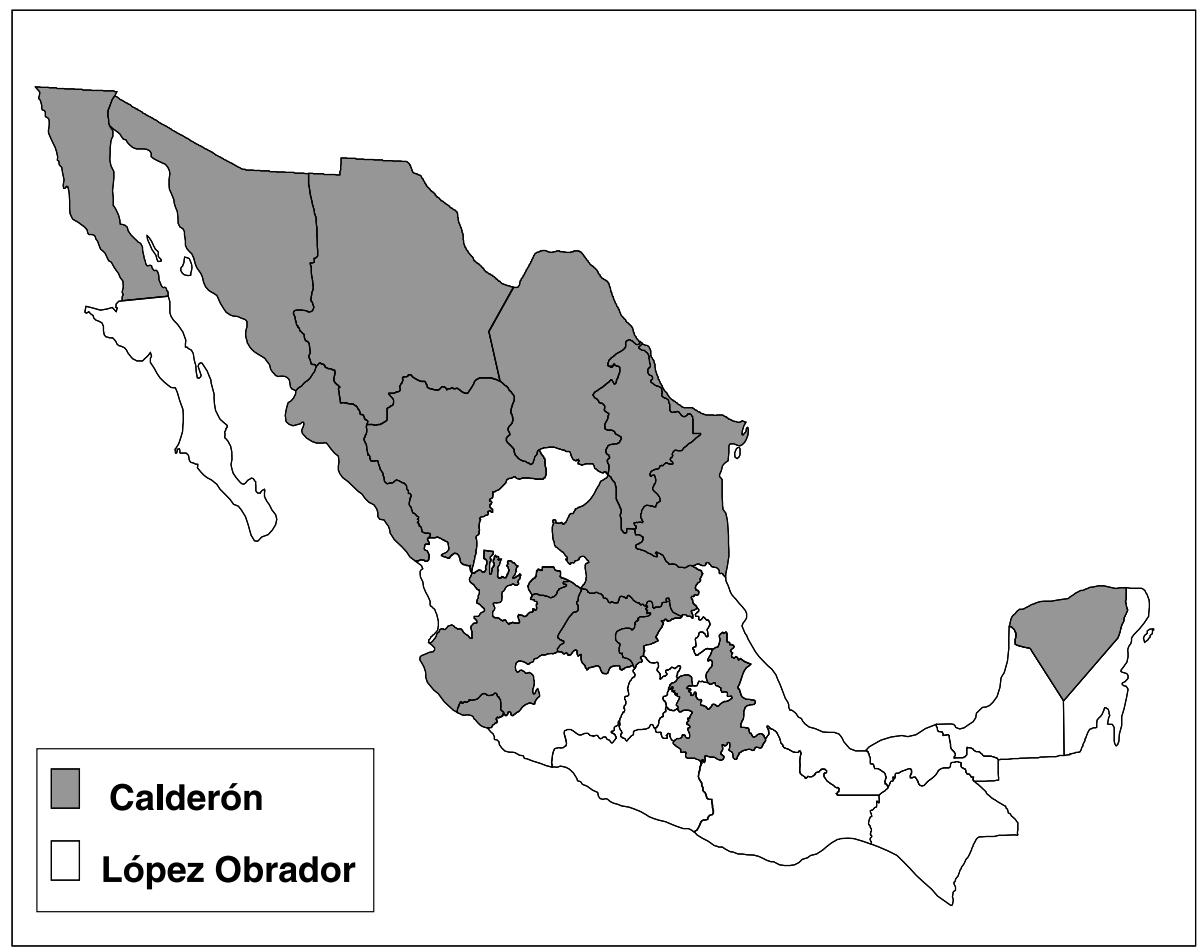

PRI's Madrazo was the candidate that gained most of the votes from the poor, as has been the case for PRI candidates for many years (Klesner 2005). These findings mirror those for educational levels. A strong positive relationship between education and voting for Calderón emerges, while a powerfully inverse relationship between education level and vote share for Madrazo is clear. Again, López Obrador polled well across all educational levels.

Exploring three more socioeconomic indicator variables, we find that Calderón polled very well among those identified by the interviewer as White, whereas White Mexicans showed considerably less enthusiasm for either of his main opponents. ${ }^{5}$ Notably, Madrazo did well among darkerskinned Mexicans, indicating that the PRI continues to pull its votes disproportionately from the millions of Mexicans of indigenous heritage. Again, these figures suggest that while Calderón's support comes disproportionately from upper social strata, and the PRI's from lower social strata, López Obrador received votes across social groups.

The PRI has had a long relationship with organized labor (Middlebrook 1995), while the PAN has not. Calderón polled much more poorly among the small segment of unionized families in this survey than among those with no union associa-

and Carlos Salinas (1988-1994): a market-oriented, internationalist economic model. Calderón ran a strongly negative campaign that sought to portray López Obrador as a dangerous populist, on the model of Venezuela's Hugo Chávez, who would polarize the country and endanger the economic gains made in the last three years of the Fox administration.

Table 1 reports cross-tabulations of several of the electorates' key demographic and socioeconomic characteristics alongside voters' self-reported vote in the presidential election. We see that López Obrador polled much more strongly among men than women, with Calderón winning more of the women's vote. Mexican men's vote for López Obrador is easier to understand in the context that they are more willing risk-takers than Mexican women. In 2000, for instance, men were more likely to vote for Fox, while women opted disproportionately for the PRI's Francisco Labastida, the virtual incumbent (Klesner 2001, 110). ${ }^{4}$

In terms of the age profile of his supporters, Calderón continued Fox's trend of performing well in age groups outside of the elderly. PRI candidate Roberto Madrazo, not surprisingly, performed best among voters over age 50, suggesting that the PRI base continues to age and that its decline in voting strength as well as partisan dealignment in Mexico probably have as much to do with the generational replacement of PRI stalwarts as anything else. López Obrador did best among those in their thirties and forties, but no worse among the young than the old. This relatively widespread support across age groups mirrors López Obrador's relative success across different categories on the various socioeconomic variables explored here.

Moving to socioeconomic factors, we see that Calderón clearly polled better among higher-income groups than with poorer voters. However, despite his special appeal to the poor, López Obrador gathered votes at similar rates across all income groups, with the possible exception of the richest Mexicans. The tions; Madrazo performed better among union families. Despite his populist rhetoric, López Obrador received votes in almost the same proportions from union and non-union families. Of course, as organized labor has withered, this population segment is growing smaller and smaller. On the other hand, Calderón and the PAN had greater success in winning the votes of those with family members working in the U.S. Those families may have both economic interests in good relations with the U.S. and a more favorable view of the U.S. than those with no family members working across the border.

While religious issues have been at the root of much violent conflict in post-independence Mexico, in recent decades religion has not been central in shaping the major issues on the public agenda. As Bruhn and Greene note in their article in this symposium, although the party elites for the PAN and the PRD are quite divided on moral issues like abortion, those themes did not prove central mobilizers of opinion in the campaign. The PAN, however, has clearly identified itself as proCatholic since its founding. Bishops have also been willing to speak out on political positions over the past two decades, especially in promoting participation and democratic change (Chand 2001). In 2006, Catholics-especially church-goerswere more likely to vote for Calderón than Protestants, those with no religion, and those who rarely attend religious services. López Obrador, meanwhile, did especially well among the non-religious, although again this is a small segment of the population.

These results, along with those for the age profile of the candidates' supporters, suggest that while Calderón did draw votes disproportionately from the younger, the better-educated, and those with higher incomes, López Obrador's voters spanned the spectrum of socioeconomic groups. The PRI vote remains concentrated among the less-educated, the poor, and the old. Note too that the PRI continues to draw its votes 


\section{Table 1}

Socioeconomic Characteristics and Presidential Vote, 2006

\begin{tabular}{|c|c|c|c|c|}
\hline & $\begin{array}{l}\text { Felipe } \\
\text { Calderón }\end{array}$ & $\begin{array}{l}\text { Roberto } \\
\text { Madrazo }\end{array}$ & $\begin{array}{l}\text { Andrés Manuel } \\
\text { López Obrador }\end{array}$ & $\begin{array}{l}\text { Percent } \\
\text { of Sample }\end{array}$ \\
\hline \multicolumn{5}{|l|}{ Sex } \\
\hline Male & 35.1 & 19.1 & 38.4 & 48.1 \\
\hline Female & 46.2 & 17.7 & 27.9 & 51.9 \\
\hline \multicolumn{5}{|l|}{ Age } \\
\hline $18-29$ & 42.9 & 17.1 & 30.5 & 24.3 \\
\hline $30-49$ & 43.1 & 15.4 & 36.7 & 45.2 \\
\hline $50+$ & 35.7 & 24.0 & 29.3 & 30.5 \\
\hline \multicolumn{5}{|l|}{ Rural/urban } \\
\hline Rural/mixed & 35.0 & 26.6 & 33.6 & 32.8 \\
\hline Urban & 43.8 & 14.4 & 32.6 & 67.2 \\
\hline \multicolumn{5}{|c|}{ Monthly income (10 pesos $\approx$ US\$1) } \\
\hline Less than 2,000 pesos & 35.1 & 23.9 & 35.6 & 21.6 \\
\hline $2,000-4,000$ pesos & 38.3 & 18.9 & 36.4 & 23.7 \\
\hline $4,000-9,000$ pesos & 43.2 & 15.0 & 34.2 & 26.9 \\
\hline More than 9,000 pesos & 52.7 & 11.5 & 27.9 & 18.9 \\
\hline \multicolumn{5}{|l|}{ Education level } \\
\hline None & 39.2 & 13.7 & 25.5 & 5.9 \\
\hline Primary & 36.8 & 24.6 & 32.1 & 32.1 \\
\hline Secondary & 41.7 & 20.3 & 32.8 & 22.0 \\
\hline Preparatory & 41.2 & 14.5 & 37.0 & 18.9 \\
\hline University & 47.2 & 10.6 & 32.8 & 20.7 \\
\hline \multicolumn{5}{|l|}{ Skin color } \\
\hline White & 48.0 & 14.3 & 27.4 & 20.1 \\
\hline Light brown & 39.1 & 17.8 & 35.4 & 49.0 \\
\hline Dark brown & 39.2 & 21.6 & 32.8 & 30.8 \\
\hline \multicolumn{5}{|l|}{ Union member in family? } \\
\hline Yes & 34.4 & 23.7 & 33.3 & 10.8 \\
\hline No & 41.5 & 17.8 & 33.0 & 89.2 \\
\hline \multicolumn{5}{|c|}{ Close relatives work in U.S.? } \\
\hline Yes & 43.9 & 18.9 & 30.1 & 53.4 \\
\hline No & 37.9 & 17.5 & 35.9 & 46.0 \\
\hline \multicolumn{5}{|l|}{ Religion } \\
\hline Catholic & 42.9 & 18.5 & 31.7 & 84.4 \\
\hline Protestant & 35.0 & 21.7 & 38.3 & 6.9 \\
\hline Other & 18.8 & 25.0 & 31.3 & 1.8 \\
\hline None & 28.6 & 9.5 & 42.9 & 4.8 \\
\hline \multicolumn{5}{|c|}{ Frequency of church attendance } \\
\hline At least weekly & 43.7 & 18.5 & 29.7 & 49.6 \\
\hline Once a month & 45.1 & 15.5 & 33.1 & 16.5 \\
\hline Occasionally & 36.1 & 20.4 & 36.9 & 29.5 \\
\hline Never & 31.6 & 13.2 & 36.8 & 4.4 \\
\hline
\end{tabular}

Source: Mexico 2006 Panel Study, post-election wave (July 15-30, 2006).

Cells show row percentages. Rows do not sum to $100 \%$ because respondents who voted for other candidates and those who refused to answer are not reported.

\section{Regionalism}

Beyond these observations, voters in the north and the center-west favored Calderón and those in the center and south supported López Obrador, as Figure 1 shows. Multiple regression analysis of countylevel aggregate data confirms that region is a strong predictor of the share of the vote won by the three major candidates (Klesner 2006), a finding that mirrors those uncovered by analysis of individual-level data from the Mexico 2006 Panel Study (Lawson 2006). However, blue and yellow Mexico allows no place for the green-and-red of the PRI. Madrazo, of course, ran an abysmal campaign, as Langston shows in her article in this symposium. PRI congressional candidates performed much better than their standard-bearer, with the PRI and its coalition partner taking $28.2 \%$ of the popular vote nationally (compared to $29.0 \%$ for the PRD-led coalition's candidates and $33.4 \%$ for the PAN). The PRI also governs the majority of Mexican states, with 17 governors, including every border state except Baja California and most states of the south, other than Morelos and Yucatán (PAN) and Guerrero and Chiapas (PRD).

Figure 2 offers a more complex vision of regionalism in the 2006 election, using results in the much closer Chamber of Deputies races to chart patterns of party competition. Where a party won by a margin of greater than $15 \%$, I placed the state in a one-party dominance category. Where no more than 15 points separate the first and the third parties, I put the entity in the three-way competition classification. Otherwise, I categorized the states by the two parties that competed for first and second places. Here we still see regionalism, but a much more variegated one. The PAN dominates the center-west region, and it competes against the PRI in the northern states, with many of the margins very close even in this year in which the PRI

primarily from the countryside, whereas both the PRD and the PAN are urban-based parties. Catholics, especially the more religious, tend to vote for the PAN, while the party does poorly among the non-religious, who support the PRD. Women felt more comfortable voting for Calderón than for López Obrador. So while there is some evidence of class and religion shaping vote decisions, particularly for the PAN and the PRI, the part of the electorate supporting López Obrador's PRD cannot be understood in class or religious terms, although there is a modest religious influence. standard-bearer had very short coattails. The PRD dominates the Federal District and Michoacán, and competes hard with the PRI in the southern states of Guerrero, Chiapas, and Tabasco (the last home to both Madrazo and López Obrador). In gubernatorial elections held since July 2006, the PRD beat the PRI by a whisker in Chiapas but lost Tabasco to the PRI. Most of the other states now see three-party competition, most of them located across the broad middle of the country.

At the state level, then, Mexico is not so easily divided into blue and yellow. Here PAN or PRD militants may not be 
Figure 2

\section{Patterns of Party Competition}

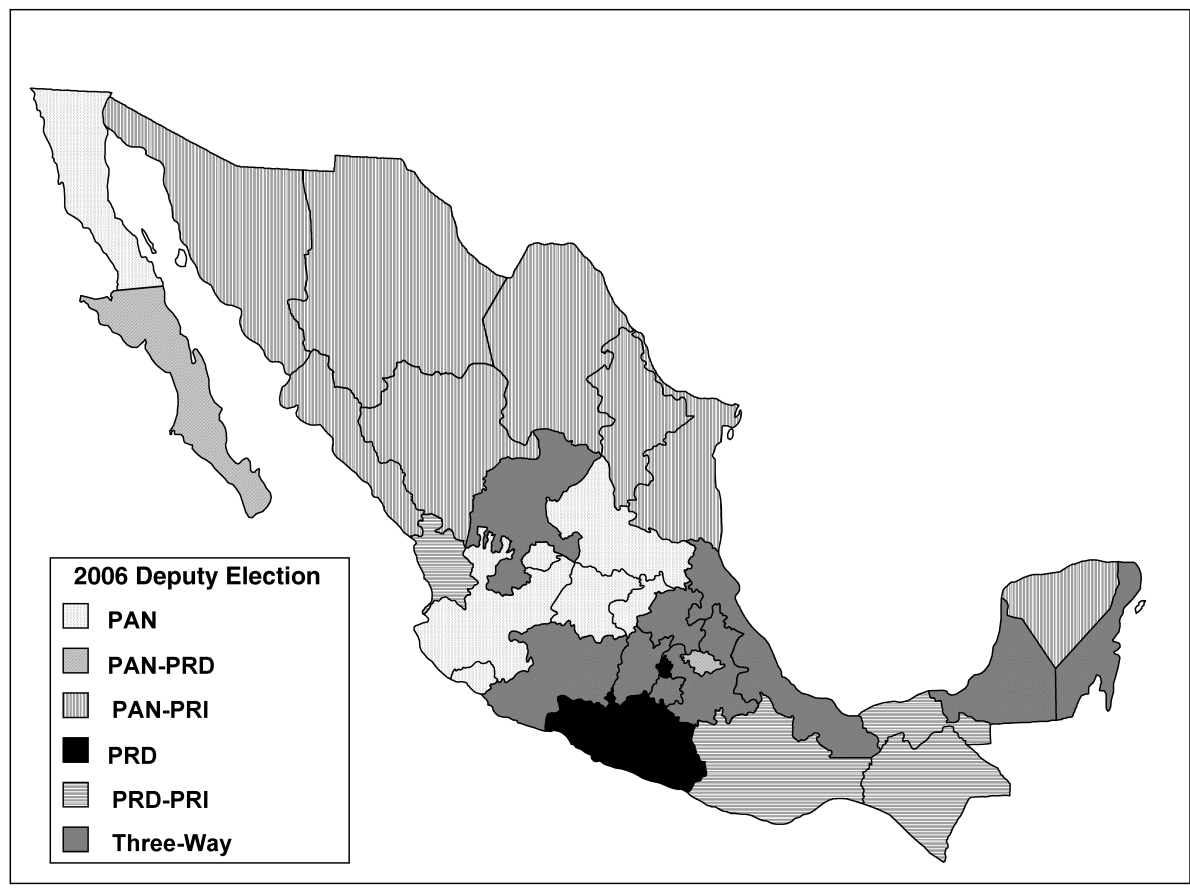

PRD in 2006. Four out of five respondents to the Mexico 2006 Panel Study who voted for PRD nominee Cuauhtémoc Cárdenas in 2000 voted for López Obrador this year, while Calderón took only three out of five who chose Fox six years ago. At this juncture, the PRD voter base appears to be the most solid and loyal of the three major parties, although the PAN has also built a loyal following. In contrast, a much higher percentage of self-declared PRI partisans defected, and many more PRI voters split their ballots. Only half of those who voted for the PRI candidate in 2000 cast ballots for Madrazo. Of course, many whose votes pushed Fox into the presidency also defected in 2006, with those not voting for Calderón going overwhelmingly for López Obrador. Many Fox voters had, it should be remembered, swung over to Fox's message of regime change, with little interest in the PAN's policy orientation (Klesner 2001), and to the extent that a segment of the electorate remains committed to profound societal change, it voted for López Obrador this year. Both Cárdenas in 2000 and López Obrador in 2006 performed especially well among voters on the Left, but Calderón voters were more clearly on the Right than Fox voters had been six years ago-again, Fox drew change-oriented voters from across the ideological spectrum.

Yet Calderón won the election, and that he did so owes much to President Fox, despite their testy relationship. ${ }^{6}$ While a majority of those respondents who thought that Fox had not wrought important changes chose López Obrador on Election Day, that portion of the electorate was less than one-third of all respondents in our sample. Calderón, meanwhile, took more than half of the votes of the much larger segment of the sample that believed Fox did bring important changes to his country. Similarly, those who approved of Fox's performance voted at much higher rates for Calderón than for his principal rival-and $65 \%$ of respondents gave Fox a positive approval rating. Although I do not report the evidence here, Calderón also did much better than López Obrador among those whose current and retrospective evaluations of economic conditions (both sociotropic and pocketbook evaluations) were positive, as Alejandro Moreno indicates in his contribution to this symposium.

Calderón also owes his victory to an effective campaign. The bottom panel of Table 2 provides evidence of campaign effects. A virtue of our panel-study design is that we can observe changes in voting intention over the course of the campaign. Of those who expressed an intention to vote for Calderón in October 2005, 85.0\% actually followed through in July. López Obrador was less successful in holding his October supporters through to the July elections, retaining only $72.6 \%$ of them; nearly $20 \%$ moved to Calderón's camp by Election Day. Calderón defeated López Obrador by winning larger numbers of PRI defectors and undecided voters. The disproportionate defection of voters from Madrazo may reflect strategic voting by PRI supporters who, when faced with strong evidence (as reported in opinion polls) that their candidate was unlikely to win, chose what they deemed the lesser of two evils-or picked the candidate promising continuity over the one advocating change.

Analysis of the defectors (those who did not vote the way they indicated they would when asked in October; the analysis is not reported here) suggests that their most important
First, partisan identity has emerged as a very strong indicator of voting behavior, and it seems to have mattered most for the 
Table 2

Political Characteristics and Presidential Vote, 2006

\begin{tabular}{|c|c|c|c|c|}
\hline & $\begin{array}{l}\text { Felipe } \\
\text { Calderón }\end{array}$ & $\begin{array}{l}\text { Roberto } \\
\text { Madrazo }\end{array}$ & $\begin{array}{l}\text { Andrés Manuel } \\
\text { López Obrador }\end{array}$ & $\begin{array}{l}\text { Percent } \\
\text { of Sample }\end{array}$ \\
\hline \multicolumn{5}{|l|}{ Partisan identity } \\
\hline PAN & 90.3 & 2.0 & 4.9 & 28.4 \\
\hline PRI & 14.8 & 72.5 & 6.0 & 20.9 \\
\hline PRD & 2.7 & 1.1 & 93.5 & 21.1 \\
\hline Independent or refused to answer & 39.1 & 8.2 & 35.9 & 29.4 \\
\hline \multicolumn{5}{|l|}{ Vote in 2000} \\
\hline Did not vote & 38.6 & 15.9 & 35.6 & 15.2 \\
\hline Vicente Fox (PAN) & 61.3 & 7.0 & 27.9 & 41.2 \\
\hline Cuauhtémoc Cárdenas (PRD) & 9.3 & 4.0 & 81.3 & 8.6 \\
\hline Francisco Labastida (PRI) & 23.6 & 46.7 & 24.1 & 22.4 \\
\hline DK/NA & 29.4 & 19.6 & 27.5 & 11.7 \\
\hline \multicolumn{5}{|l|}{ Chamber of Deputies vote } \\
\hline PAN & 84.2 & 3.3 & 9.5 & 38.6 \\
\hline PRI/Alliance for Mexico & 14.4 & 65.8 & 14.4 & 23.2 \\
\hline PRD/Coalition for the Welfare of All & 7.7 & 1.7 & 87.2 & 27.0 \\
\hline \multicolumn{5}{|l|}{ Ideology } \\
\hline Left & 22.5 & 18.0 & 55.1 & 20.4 \\
\hline Center & 40.3 & 17.0 & 31.9 & 33.1 \\
\hline Right & 56.0 & 19.4 & 21.1 & 20.1 \\
\hline None & 47.4 & 12.3 & 29.8 & 13.1 \\
\hline DK/NA & 41.4 & 26.7 & 22.4 & 13.3 \\
\hline \multicolumn{5}{|l|}{$\begin{array}{l}\text { Has President Fox brought important } \\
\text { changes to Mexico? }\end{array}$} \\
\hline Yes & 54.9 & 15.7 & 22.1 & 65.0 \\
\hline No & 14.8 & 22.4 & 54.8 & 30.2 \\
\hline \multicolumn{5}{|l|}{ Presidential approval } \\
\hline Highly approve & 73.0 & 11.2 & 10.7 & 22.5 \\
\hline Somewhat approve & 48.1 & 19.4 & 26.6 & 42.7 \\
\hline Neither & 28.6 & 18.4 & 38.8 & 5.6 \\
\hline Somewhat disapprove & 9.9 & 21.5 & 57.0 & 13.9 \\
\hline Highly disapprove & 3.1 & 21.6 & 66.0 & 11.1 \\
\hline DK/NA & 13.9 & 27.8 & 41.7 & 4.1 \\
\hline \multicolumn{5}{|l|}{ Voting intention in October } \\
\hline Calderón & 85.0 & 2.8 & 8.5 & 24.5 \\
\hline Madrazo & 26.8 & 53.1 & 15.0 & 24.5 \\
\hline López Obrador & 19.1 & 4.2 & 72.6 & 33.1 \\
\hline Other/None/DK/NA & 40.1 & 18.5 & 17.8 & 18.0 \\
\hline
\end{tabular}

Source: Mexico 2006 Panel Study.

Cells show row percentages. Rows do not sum to $100 \%$ because respondents who voted for other candidates and those who refused to answer are not reported.

\section{Conclusions}

Andrés Manuel López Obrador ran a campaign of change for Mexico-not regime change, such as promised by Vicente Fox in 2000 , but change in socioeconomic policy that would benefit the poor. Despite his populist rhetoric, he won a broad crossclass alliance of supporters to his cause. Notwithstanding their social differences, López Obrador voters shared a pro-Left orientation and a sense that the incumbent Fox administration had not brought profound change to Mexico, especially in regards to socioeconomic development.

During the course of the race, López Obrador's image came to be framed by two forces outside his own campaign. First, international media obsession with the "turn to the Left" in Latin America framed the Mexican election as part of a hemispheric rejection of the U.S. and of the neoliberal economic model advocated under the "Washington Consensus." López Obrador came to be seen as the Mexican embodiment of the leftist phenomenon most closely associated with Venezuela's Hugo Chávez and Bolivia's Evo Morales, although almost all observers regarded him as far less radical. Second, Felipe Calderón's media team effectively exploited that theme by suggesting to the public that López Obrador would undo the accomplishments, modest though they were, of the Fox administration and, perhaps more importantly, imperil relations with the U.S. The social groups most threatened by those potentialities - the better-educated, those of higher incomes, those with family links to the U.S.- - voted disproportionately for Calderón. To the extent

distinguishing features are not socioeconomic and demographic in character, but have to do with their evaluations of the economy and the sitting government (this supports the conclusions in Moreno's contribution to this symposium). For example, only $22.7 \%$ of those who stayed with López Obrador from October to July said that the economic situation of the nation had improved under Fox. In contrast, $47.4 \%$ of López Obrador defectors gave a positive sociotropic evaluation of the economy over the past six years. Fifty percent of those who left Madrazo for Calderón saw the economy as improving under the incumbent president, compared to $29.1 \%$ of those who remained loyal to Madrazo. Similar figures emerge for respondents' retrospective evaluations of their personal economic situations and their assessment of current (in July) political and economic conditions. that a north-south (blue-yellow) cleavage defines Mexican politics, these worries reinforce it because northerners have benefited most from close ties with the U.S. and from the economic changes brought about by neoliberalism. These Mexicans are the same voters who think that Fox has brought positive change to Mexico and that the economy has been performing well.

The evidence I have presented here also tells us that López Obrador's camp includes a core of diehard PRD loyalists who voted for the party's presidential candidate six years ago and for the party's legislative candidates this year, and who stood loyal with López Obrador despite a very negative campaign by Calderón. As Bruhn and Greene's article suggests, these PRD supporters may not differ so much from PAN supporters on policy issues as do PRD and PAN party elites-but they do identify strongly with the PRD. When we combine that observation 
with the election's razor-thin margin and the presence of just a few electoral irregularities, perhaps we should not be surprised by the vehemence with which many of those López Obrador voters supported his protest movement. This segment of the population remains a minority, but a very vocal one that Calderón must incorporate back into ordinary politics as he governs his nation over the next six years.

But Mexico is not yet a two-party system. Although its leader ran an abysmal campaign in 2006 (see Langston's contribution to this symposium), the PRI has an important presence in state government and takes more than a quarter of votes at the na-

\section{Notes}

1. The PAN's colors are blue and white, the PRD's yellow (the Mexican sun) with black.

2. The data are available for download at www.ife.org.mx/documentos/ computos2006/index_computos.htm (last accessed on October 22, 2006). These results are the results of the Computo Distrital (district-level totals), the final tallies from the Federal Electoral Institute (IFE). Because the changes made to the vote totals by the Federal Electoral Tribunal (TRIFE) were very small, it will not materially affect the analysis to use the earlier IFE figures.

3. Senior Project Personnel in the Mexico 2006 Panel Study include (in alphabetical order): Andy Baker, Kathleen Bruhn, Roderic Camp, Wayne Cornelius, Jorge Domínguez, Kenneth Greene, Joseph Klesner, Chappell Lawson (Principal Investigator), Beatriz Magaloni, James McCann, Alejandro Moreno, Alejandro Poiré, and David Shirk. Funding for the study was provided by the National Science Foundation (SES-0517971) and Reforma newspaper; fieldwork was conducted by Reforma newspaper's Polling and Research Team, under the direction of Alejandro Moreno. Because of the panel-study design, we cannot guarantee that the post-election wave of the panel survey, which I use extensively in this article, provides a representative sample. Indeed, our surviving sample gives a larger advantage to

\section{References}

Ansolabehere, Stephen, Jonathan Rodden, and James M. Snyder, Jr. 2006 "Purple America." Journal of Economic Perspectives 20 (spring): 97-118.

Bruhn, Kathleen, and Kenneth Greene. 2007. "Elite Polarization Meets Mass Moderation in Mexico's 2006 Elections." PS: Political Science and Politics 40 (January): man-man.

Chand, Vikram K. 2001. Mexico's Political Awakening. Notre Dame: University of Notre Dame Press.

Consulta Mitofsky. 2006. "2 de julio de 2006, análisis de la elección: encuesta de salida." Available at http://207.56.94.3/interiores/99_pdfs/ 11_elecciones_pdf/20060702_ExitPoll_PerfilVotante.pdf (last accessed on October 22, 2006).

Gimpel, James, and Kimberly Karnes. 2006. "The Rural Side of the UrbanRural Gap." PS: Political Science and Politics 39 (July): 467-72.

Gimpel, James, and Jason Schuknecht. 2003. Patchwork Nation: Sectionalism and Political Change in American Politics. Ann Arbor: University of Michigan Press.

Klesner, Joseph L. 2001. “The End of Mexico's One-Party Regime.” PS: Political Science and Politics 34 (March): 107-14.

- 2005. "Electoral Competition and the New Party System in Mexico." Latin American Politics and Society 47 (summer): 103-42. tional level. Unless the PRI implodes and its rural, poor, indigenous voters move to the PRD, the former ruling party will continue to serve as a buffer between the PAN and the PRD, deflecting some of the potential for class conflict and complicating the north-south divisions. Post-electoral conflict is evidence of potentially deep divisions among Mexican elites (see Chappell Lawson's contribution to this symposium), but the cleavage patterns (or lack of them) manifested on Election Day itself offer some comfort that Mexican society at the mass level displays no such divisions.
Calderón (40.9 to 33.0\%), than occurred in the election itself. Of the 1,600 respondents in the initial October wave of the panel, 871 remained in the post-election wave in July.

4. Mexican presidents cannot stand for reelection. However, until Fox upended the PRI in 2000, PRI nominees were widely regarded as the handpicked choices of the actual incumbents, the outgoing PRI presidents, and hence can be regarded as the functional equivalent of incumbents.

5. Skin color is a marker of class status in Mexico, with whiter-skinned persons typically enjoying higher education, living standards, and social status. An interviewer's coding of skin color cannot, of course, establish a respondent's self-perception of where she fits into racial categories. In general though, those of darker-brown skin are more likely to be of indigenous parentage.

6. Fox hails from the neopanista wing of the PAN, while Calderón has his closest links to the traditionalist core of the party. The latter group regards the former group as opportunistic and insufficiently committed to the party's principles. Calderón served as Fox's energy minister (2003-2004) but left the administration in protest when it became clear that Fox favored Santiago Creel in the presidential succession. 